\title{
The Empirical Research on the CET-4 Listening Comprehension Test of the Vocational Students
}

\author{
Linxian Liu \\ Foreign Language Department, Wuhan College of Foreign Languages and Foreign Affairs, Wuhan \\ 410000, China \\ 750900806@qq.com
}

Keywords: College English Test-4; vocational college, CET-4 listening comprehension test; empirical research

\begin{abstract}
The purpose of learning a language is communication, and listening is the most frequently used mode in human communication. CET-4 is one of the largest foreign language test in our country at present. For the vocational students, because of their special characteristics, their listing level cannot be compared with those ordinary university students. This paper tends to make the empirical research on the influence of the CET-4 listening comprehension test on English teaching and its problems, so as to improve the current English listening teaching.
\end{abstract}

\section{Introduction}

Listening, as one of the most important parts of language communication, is an important means for human to obtain and express information. In the process of second language acquisition, listening ability not only can prove learners' language communication ability, but also serve as an important bridge between reading skills and writing skills. It can be seen that listening is of great importance in language learning. However, China's English listening teaching is still relatively weak, especially weak in the higher vocational education. College English test band 4 (CET-4) is one of the most authoritative foreign language tests in China. A lot of researches have been done on this test and many suggestions and methods for improvement have been put forward. However, there are few researches about CET-4 listening test, the empirical research on CET-4 listening test for higher vocational students is almost blank. Therefore, this paper attempts to make an empirical study on the impact of CET-4 listening test on the listening teaching of higher vocational colleges and its problems, so as to promote college English listening teaching of higher vocational colleges and improve the listening level of English learners. 


\section{Research Design}

\subsection{Research Object}

This study investigates 10 college English teachers and 80 non-english majors at Wuhan College of Foreign Languages and Foreign Affairs(FLFA). The 80 students surveyed are randomly selected from sophomore of non-english majors aged between 18 and 21who have been learning English for at least seven years.

\subsection{Research methods}

In this study, the author use three research tools: questionnaire, interview and classroom observation. The questionnaire is designed for students on the basis of listening theory and mainly consists of two parts. The first part is about personal information, including age, gender, major, grade, etc. The second part is subjective questions, including the influence of CET-4 listening test on English listening teaching, main methods and objectives of English listening learning, English listening classroom activities, CET-4 preparation methods, etc. Interviews are conducted separately for teachers and students. Interviews with teachers and students mainly cover seven aspects: attitudes of listening learners, objectives, classroom time allocation, selection of teaching materials, teaching methods, views on CET-4 listening test and suggestions for improving the effectiveness of the test. Classroom observation is conducted by selecting a CET-4 listening preparation class from the second year of flight attendant majors and Japanese majors respectively, so as to test whether the actual classroom effect is consistent with the interviewee's conversation.

\subsection{Research Objective}

In this study, SPSS 10 is used for data analysis, and the research results are mainly discussed in the following aspects:(1) learners' views on and evaluation of CET-4; (2) the impact of CET-4 on college English listening teaching (3) the basic situation analysis of current CET-4 classroom teaching and its improvement suggestions.

\section{Research Analysis}

\subsection{The Analysis of Questionnaires}

This study conducts a questionnaire survey among 80 non-english majors at FLFA. According to the SPSS analysis, the following results are obtained:

Table 1 The influence of CET-4 listening test on English listening teaching

\begin{tabular}{|l|l|l|l|l|}
\hline Positive Impact & Negative Impact & Positive $>$ Negative & Negative>Positive & No Impact \\
\hline $11 \%$ & $3.3 \%$ & $48.3 \%$ & $22 \%$ & $15.3 \%$ \\
\hline
\end{tabular}

It can be seen from Table 1 that $85 \%$ of students believe that CET-4 listening test has an influence on English listening teaching, and 59.3\% of students think that CET-4 listening test has a positive influence on English listening teaching or a positive influence is greater than a negative one. This proves that most students have recognized the fundamental purpose and function of CET-4 listening test and recognize its powerful influence. Table 2 describes the influence of CET - 4 listening test on English listening learning from different aspects. Different from Table 1, students in Table 2 think 
CET - 4 listening test has more negative effects than positive effects on learning objectives, learning methods, learning materials, learning interest, which proves that the listening test of CET - 4 didn't fundamentally mobilize students to study, thus affecting the improvement of the students listening level.

Table 2 The effects of CET-4 listening test on various factors of English listening learning

\begin{tabular}{|l|l|l|l|l|l|}
\hline $\begin{array}{l}\text { Factors in } \\
\text { English listening } \\
\text { Learning }\end{array}$ & $\begin{array}{l}\text { Positive } \\
\text { Impact }\end{array}$ & $\begin{array}{l}\text { Negative } \\
\text { Impact }\end{array}$ & $\begin{array}{l}\text { Positive }> \\
\text { Negative }\end{array}$ & $\begin{array}{l}\text { Negative> } \\
\text { Positive }\end{array}$ & No Impact \\
\hline $\begin{array}{l}\text { LLearning } \\
\text { Objectives }\end{array}$ & $77.3 \%$ & $55 \%$ & $331.4 \%$ & $447 \%$ & $99.3 \%$ \\
\hline $\begin{array}{l}\text { LLearning } \\
\text { Methods }\end{array}$ & $111.7 \%$ & $12 \%$ & $331.3 \%$ & $449.7 \%$ & $55.3 \%$ \\
\hline $\begin{array}{l}\text { LLearning } \\
\text { Materials }\end{array}$ & $78 \%$ & $11.3 \%$ & $331.3 \%$ & $447 \%$ & $113 \%$ \\
\hline $\begin{array}{l}\text { LLearning } \\
\text { Interest }\end{array}$ & $111.7 \%$ & $12.0 \%$ & $331.3 \%$ & $349.7 \%$ & $55.3 \%$ \\
\hline
\end{tabular}

\subsection{The Analysis of Interviews}

In the interview, 10 teachers present their opinions on CET-4 listening test. Teachers believe that the CET-4 listening test has a positive impact on college English listening teaching and learning. However, many teachers think that higher vocational college students' listening level is generally poor, English listening teaching is closely related to the level of students, the class size and teaching objectives. They consider teachers should try to change the teaching methods to improve the students' learning motivation and learning interest, so as to fundamentally enhance the students' listening level and ability, not just aim to pass the CET 4.

In the interview, the students are asked about their views on the English listening class. Most students are skeptical about the traditional listening class activities. The students think that not all students could participate in the listening and speaking activities within the limited time. Due to the poor level and the pressure of CET-4 examination, students do not have much interest in learning about the listening textbook content and practical activities, but rather spend a lot of time to deal with the model tests and books of CET-4 listening test, and teachers are advised to choose the content of CET-4 listening test in class for training to prepare for the test.

\subsection{The Analysis of Classroom Observation}

This study is to observe the English listening classes of class 3 of flight attendant major and class 1 of Japanese major of FLFA, including teaching materials, teaching methods, classroom activities and atmosphere, mental state of teachers and students, and students' participation and interaction. The observation results are as follows:

Table 3 Classroom observation of two classes

\begin{tabular}{|c|c|c|c|c|c|}
\hline Class & $\begin{array}{c}\text { Teaching } \\
\text { Methods }\end{array}$ & Teaching Materials & Atomsphere & $\begin{array}{c}\text { Mental } \\
\text { State }\end{array}$ & Interaction \\
\hline $\begin{array}{c}\text { Class 3 of Fight } \\
\text { Attendant Major }\end{array}$ & Traditional & CET-4 Listening Test & Quiet & Serious & Little \\
\hline $\begin{array}{c}\text { Class 1 of Japanese } \\
\text { Major }\end{array}$ & Communicative & Warming-up Listenig & Active & Relaxed & Much \\
\hline
\end{tabular}

As can be seen from Table 3, the teacher of flight attendant class 3 use the traditional teaching 
method, directly entered the test of CET-4 listening without any extracurricular listening materials, and repeated the recording and dictation in class. The classroom interaction is little, the classroom atmosphere is very serious, the students' study enthusiasm is not high. However, the communicative method adopted by Japanese class 1 starts with the introduction of a current event listening material and the listening skills when doing news materials before the formal listening content. In the process of dictation, students are asked to discuss their answers in groups, guess the correct answers, imitate the pronunciation and intonation of the original recording for dialogue. The classroom atmosphere is very good. This shows that different teaching methods will yield different teaching effects, and the traditional teaching method of "preparing for exams" will greatly affect students' learning motivation and interest.

\section{Summary}

This study finds that CET-4 listening test can promote and improve college English listening, teaching and learning to a certain extent, but it also has negative effects on "exam-oriented" teaching and learning, because students aim to pass CET-4, rather than improve their listening ability and level. In view of this phenomenon, this paper tries to put forward the following suggestions: (1) select suitable listening materials: do not always select materials that may appear in the CET-4 listening test for practice. (2) diversify the forms of examination: at present, CET-4 listening questions mainly focus on choosing and filling in words, accounting for a large score, which is not conducive to improving students' listening ability. The test should increase the sections like dictation, general summary, sentence correction and other subjective questions to truly guide and test students' listening ability. (3) popularize oral tests: currently, only a small number of students take part in the speaking test, because the speaking test does not affect the CET - 4 grades of the students, which makes the students spent a lot of energy to cope with the written test, and speaking ability is not improved. The spoken section should be integrated into a necessary part of CET - 4 grades, thus language communication ability can obtain the real ascension.

\section{References}

[1] Dayong Huang, The concept of authenticity in language testing [J], Language teaching and research, (2): 77-80. (2004).

[2] Runqing Liu, Baocheng Han, Language testing and its methods [M], Beijing: foreign language teaching and research press. (1999).

[3] Huizhong Yang, The current practical English proficiency of Chinese college students from the CET4 and CET6 [J], foreign languages (1). (2000).

[4] Huizhong Yang, Review of 15 years of CET-4 and CET-6 [J]. Foreign languages, (3): 21-29. (2003).

[5] Shen Zou, Language testing [M], Shanghai: Shanghai foreign language publishing house education. (2005). 